\title{
A Restatement of Corporate Freezeouts
}

\author{
Victor Brudney† and Marvin A. Chirelstein $\ddagger$
}

Apparently overruling earlier decisions, the Supreme Court of Delaware has recently declared that a merger effected "for the sole purpose of freezing out minority stockholders . . . is an abuse of the corporate process ... [and a] violation of a fiduciary duty for which the Court may grant ... relief."1 In Singer v. Magnavox Co.," a parent corporation had merged with its eighty-four-percent-owned subsidiary. Minority stockholders of the subsidiary had received only cash for their shares and thus had been eliminated from participation in the combined enterprise. The court confirmed that the parent owed a fiduciary duty to the minority by reason of its status as majority stockholder, but then-in what is generally viewed as a new development in Delaware law-the court held that this duty would not be met unless a corporate purpose for the merger, other than mere elimination of the minorityheld stock, were supported by the evidence.

In Tanzer v. International General Industries, Inc., ${ }^{3}$ decided a few weeks after Singer, the court resolved the question of whose corporate purpose was relevant in parent-subsidiary mergers by holding that a merger that conveyed an economic benefit to the parent corporation sufficed to meet the standard of fiduciary conduct erected in Singer, provided that the transaction was otherwise "entirely fair" to the minority stockholders of the subsidiary. In effect, the displacement of a subsidiary's public stockholders was held to be lawful under the Delaware statute if, but only if, a commercial benefit could be demon-

$\dagger$ Professor of Law, Harvard University.

$\mp$ William Nelson Cromwell Professor of Law, Yale University.

1. Singer v. Magnavox Co., 380 A.2d 969, 980 (Del. 1977). The Singer court distinguished cases refusing to enjoin freezcout mergers by stating that "none of these decisions involved a merger in which the minority was totally expelled via a straight 'cash-for-stock' conversion in which the only purpose of the merger was, as alleged here, to eliminate the minority." Id. at 978. For example, the court observed that Stauffer v. Standard Brands Inc., 41 Del. Ch. 7, 187 A.2d 78 (1962), which held that appraisal was the minority's only remedy against an allegedly unfair freezeout price, did not approve "a merger accomplished solely to frecze-out the minority without a valid business purpose." 380 A.2d at 979. Similarly, the court wrote that David J. Greene \& Co. v. Schenley Indus., Inc., 281 A.2d 30 (Del. Ch. 1971), was inapposite because it did not involve "a 'cash-out merger,' the sole purpose of which was to eliminate minority stockholders." 380 A.2d at 979 .

2. 380 A.2d 969 (Del. 1977). The current upheaval in Delaware law may well be traceable to criticisms articulated in Cary, Federalism and Corporate Law: Reflections Upon Delaware, 83 YALE L.J. 663 (1974).

3. 379 A.2d 1121 (Del. 1977). 
strated. That benefit could be confined to the parent's interest, and thus no advantage to the subsidiary need be alleged, so long as the merger, viewed overall, was fair to the minority.

These developments in the Delaware jurisprudence are part of a rapidly growing body of modern case law, federal as well as state, on corporate freezeouts. Although the United States Supreme Court has now held that section 10(b) of the Securities Exchange Act does not empower the federal courts to create an independent common law of fiduciary obligation, ${ }^{4}$ other elements of the federal securities scheme, chiefly the proxy rules, have stimulated the federal courts to develop rules for measuring damages in the merger context that reflect a willingness to expand existing concepts and experiment with new ideas. In Mills v. Electric Auto-Lite Co., 5 the Seventh Circuit for the first time adopted an explicit sharing-of-benefits formula in determining whether the amount paid to minority stockholders of a merged subsidiary constituted fair treatment, and the Supreme Court itself, in a case arising under the Investment Company Act, has had to rule with respect to the fairness of a merger between a major operating company and the holding company that controlled it. ${ }^{6}$ Beyond these judicial developments, there appears at present to be considerable interest in the idea of a "federal minimum standards act"-legislation that would displace, and in some sense upgrade, the local law of fiduciary obligation, of which the rules on freezeouts must certainly be a part. What the "minimum standards" should be is obviously a question for debate. That such a debate is underway, however, is itself a development of note. 7

These events, actual or prospective, reflect the circumstance that litigation in the freezeout field has become exceedingly active during the past ten years. Decisions like Singer have highlighted the vulnerability of the freezeout to challenge, and it is fair to say that such transactions are almost impossible to manage at present without the expectation of dissent and litigation. This costly process may be necessary and useful for the time being. In the end, however, one hopes to see the law progress toward settled standards and a reliable basis for fair dealing between inside and outside stockholders.

Essential to any such progress are a rational classification of freezeouts

4. Santa Fe Indus., Inc. v. Green, 430 U.S. 462, 495-96 (1977).

5. 552 F.2d 1239 (7th Cir.), cert. denied, 46 U.S.L.W. 3293 (U.S. Nov. 1, 1977).

6. E. I. duPont de Nemours \& Co. v. Collins, 432 U.S. 46 (1977).

7. For a sampling of the issues and arguments, see The Role of the Shareholder in the Corporate World: Hearings Before the Subcomm. on Citizens and Shareholders Rights and Remedies of the Sen. Comm. on the Judiciary, 95th Cong., 1st Sess. (1977). 
and plausible fairness criteria for the treatment of public stockholders. A considerable body of legal writing has already been directed toward these ends, and we hesitate to add still more to the literature. But the recent Delaware decisions, though plainly intended to increase the protection of public investors, seem ambiguous in critical ways and possibly erroneous. In particular, the Singer decision, however laudable in spirit, contains two potential errors that ought to be avoided or corrected before they become fixed and general. One such error may be a failure to perceive that all freezeout transactions are not alike-that there are important contextual distinctions among freezeouts that need to be observed. As others have pointed out, freezeouts fall into three analytically distinct categories: ${ }^{8}$ (a) two-step, or integrated, mergers; (b) pure going-private transactions; and (c) mergers of long-held affiliates. The corollary, overlooked in Singer, is that different fairness criteria and different protections for minority stockholders are appropriate to each. In addition, and relatedly, the Delaware court's effort to distinguish "good" from "bad" freezeouts by use of a business purpose test was misdirected. Such a test has no role whatever to play in this field. Instead, the presence or absence of a business purpose should be treated as inherent in the categories mentioned above.

The time thus seems quite appropriate for a restatement of corporate freezeouts in clearer terms. By way of limitation, we should note that our discussion is directed solely at freezeouts involving public stockholders-roughly, stockholders who have no active role in management and whose percentage interest in the company is small. Freezeouts involving closely held firms raise issues, essentially deadlock problems, that are very different from those addressed here. ${ }^{0}$

8. See Borden, Going Private-Old Tort, New Tort or No Tort?, 49 N.Y.U.L. REv. 987, 989-1000 (1974); Green, Corporate Freezeout Mergers: A Proposed Analysis, 28 Sran. L. REv. 487, 490-96 (1976). The present authors have addressed some of the issues involved here in Brudney \& Chirelstein, Fair Shares in Corporate Mergers and Takeovers, 88 Harv. L. REV. 297 (1974) [hereinafter cited without cross reference as Fair Shares], and in Brudney, $A$ Note on "Going Private," 61 VA. L. REv. 1019 (1975).

9. In close corporations, freezeouts generally arise in the context of a dispute over the disentanglement of what are essentially partnership arrangements among more or less active participants for whose securities there is no market. See Brudney, supra note 8, at 1031; Green, supra note 8, at 513. The parties are visibly; at loggerheads over division of the business's prosperity or over the conduct of its business; their disagreements are of a continuing kind, likely both not to be resolved until the business terminates and to plague the parties as they remain unable to disentangle satisfactorily. There is, therefore, reason to facilitate or encourage the departure of one group or the other from the enterprise-both in terms of the personal well-being of the participants, and because of the impact of continuing disagreements on their conduct of the enterprise. It does not follow that corporate law should permit the controlling group to have an advantage in bargaining over the terms of the break-up. Still, the difficulty with flatly forbidding 


\section{Classification of Freezeouts}

The essence of a freezeout is the displacement of public investors by those who own a controlling block of stock of a corporation, whether individuals or a parent company, for cash or senior securities. The public investors are thus required to give up their equity in the enterprise, while the controllers retain theirs. Freezeouts most commonly take the form of a merger of a corporation into its existing parent or into a shell corporation newly formed for the purpose by those who control the merged entity.

Freezeouts, by definition, are coercive: minority stockholders are bound by majority rule to accept cash or debt in exchange for their common shares, even though the price they receive may be less than the value they assign to those shares. But this alone does not render freezeouts objectionable. Majority rule always entails coercion. It is, nonetheless, an acceptable rule of governance if all members of the voting constituency share a common goal and if all will be identically affected by the outcome of the vote. In the ordinary arm's-length merger negotiated by the managements of two unrelated corporations, stockholders of the merged entity are properly viewed as having a common interest in maximizing the returns on their stock, whether through periodic dividends or through sale or liquidation of the firm. Once approved by a statutory majority, the terms of such a merger will apply equally to each of the merging company's stockholders, and the common decision will satisfy the principle that all members of the class be treated alike. Majority rule is thus an appropriate means of deciding whether an arm's-length merger should be allowed, and it is of course a universal feature of the corporate law. Despite the element of coercion, dissenters to such a merger are bound, or remitted to an appraisal proceeding, by vote of a majority of their class, because it is

freezeouts is that, if the majority does not have the power to force the minority out, the majority may be forced to accede to the demands of the minority because of the threat of deadlock. Moreover, unlike the investors in a public corporation, the parties in a close corporation can contract in advance about their arrangements; any skew in the corporate law that permits majority power to displace the minority can thus be offset by contract. Modern statutes purport to offer special solutions for the problem of disentangling the essentially personal relationships of parties in conflict in close corporations. See, e.g., DEL. CodE tit. 8, $\$$ 352, 355 (1975); N.Y. Bus. CoR1. LAw, \$ 1104 (McKinney 1963); id. $\$ 1111(b)(3)$, (c). If, notwithstanding such legislation, freezeouts are permitted by statute, any judicially imposed solution will require compliance with some conception of "fairness," however crude it may be. But it is hard to see any role for "business purpose" as a doctrine in filtering permissible from impermissible freezeouts in close corporations, even as that conception is rigorously confined in cases like Schwartz v. Marien, 37 N.Y.2d 487 , 492, 335 N.E.2d 334, 338, 373 N.Y.S.2d 122, 127 (1975), or Wilkes v. Springside Nursing Home, Inc., 353 N.E.2d 657, 663 (Mass. 1976). 
assumed that any disagreement among the stockholders involves nothing more than a practical judgment about the best way to achieve a common aim.

Freezeouts obviously differ from arm's-length mergers in that all the members of the same class of stockholders do not receive identical treatment: the controlling stockholders retain their equity but force the minority, the public investors, to accept cash or debt. In this context, majority rule does not protect the public investor from the danger that he will be denied his pro rata share of the value of the combined company. To be sure, this danger is present even when the outside stockholders receive new common stock in the surviving company and hence are not frozen out, for the amount of common stock they receive may be insufficient. But most agree that the likelihood that public investors will be treated unfairly is greater when, as outside common stockholders, they receive cash or debt, with the insiders in effect receiving or retaining the equity. One inevitably suspects that inequality of treatment underlies the distribution of different forms of participation or payoff to members of the same class, and experience suggests that payouts to the public in cash or senior securities often reflect a temptation to undercompensate the public investors. In any event, determining whether all members of the class have in fact been treated equally is necessarily more difficult when payouts are in different forms.

All freezeouts, then, involve the distinct possibility that a self-interested majority stockholder or control group ${ }^{10}$ has ruled unfairly, and all require special safeguards to ensure that minority stockholders receive equal though not identical treatment. ${ }^{11}$ Such safeguards can

10. The reference to "majority" stockholder as the possessor of coercive power is not meant to be confined to a person or persons owning a majority of the voting stock. It includes those whose control of the enterprise through stock ownership and domination of the proxy apparatus effectively enables them to determine the terms of the merger.

11. The merger statutes, whether short-form or long-form, which authorize different formal treatment of members of the same class, do not prescribe different substantive treatment. See, e.g., DeL. CoDE tit. $8, \S 251$ (b) (prescribing contents of agreement to merge or consolidate domestic corporation), ( $f$ ) (describing conditions under which approval of merger by shareholders of surviving corporation is not required) (Supp. 1977); id. $\$ 252$ (b) (applying $\$ 251(\mathrm{~b})$ to merger or consolidation of domestic and forcign corporation), (c) (same, for $\$ 251(f)$ ) (1975 \& Supp. 1977); id. $\$ 253($ a), (d) (short-form merger provisions) (1975 \& Supp. 1977); N.Y. Bus. CoRP. LAw $\$ 902($ a)(3) (requiring merger plan to set out terms and conditions of merger) (McKinney $1963 \&$ Supp. 1977); id. $\$ 905$ (a)(2) (requiring merger plan to set forth amount and designation of affected stock), (3) (requiring merger plan to specify what consideration will be given for stock of merged corporation); id. $\S 910$ (appraisal rights for dissenting shareholders). Nor does their provision for majority vote leave unrestrained discretion in self-dealing majorities or preclude judicial imposi. tion of restrictions, including a categorical prohibition, on some hinds of actions thus authorized to be taken by a self-dealing majority. 
take various forms, ranging from antideception regulations, such as a requirement of disclosure of interest, to a flat prohibition against the action contemplated, and may include rules aimed at assuring a fair price for the minority's shares. Which, if any, of these alternatives is appropriate depends largely on the relative danger of abuse and on the social value of the objective served by the elimination of the minority interest-factors that vary with the context in which the merger occurs.

Our own view is that mergers representing merely a second step in the takeover of a target firm by a previously unrelated company present the least need for protective regulation and can be dealt with largely through the familiar medium of advance disclosure. At the other extreme, pure going-private transactions are of small value and high risk and hence should be prohibited. Mergers between affiliated operating companies, though also susceptible to abuse, at the same time promise social benefits in varying degree, and in our opinion are best regulated by rules relating to fairness of price. A strong tradition of fiduciary obligation is present in the last two situations; little or none in the first (when properly viewed). In each case the context itself defines the appropriate regulatory reaction; in none is there a need to engage in a hectic search for independent business reasons to justify the transaction.

\section{A. Two-Step Mergers}

Majority rule in cases of mergers or sales of assets between unrelated companies is an unobjectionable and universal feature of the corporate law. The stockholders of the acquired company will hold heterogeneous views on the intrinsic value of its shares, but once the acquiring company offers a price per share for the target company's assets that equals or exceeds the value assigned to those shares by a statutory majority, the case for majority rule becomes overwhelming. The alternative-to permit a single nay-voter to bar the merger-is well-nigh unthinkable, for, by compelling or encouraging stockholders to engage in hold-up behavior, it would, in effect, make mergers and sales of assets a practical impossibility. No one, presumably, would view that consequence as desirable. In conventional theory, the takeover of one company by another offers major social and private benefits in the form of improved management, and the threat of takeover is thought to operate as an essential element of market discipline upon incumbent managers. One may have reservations about how aptly the theory applies in a given case, but surely no sensible legal system would impose a rule of stockholder unanimity on the sale of a business. Some, 
indeed, have doubted whether even so mild a right of individual dissent as appraisal can be justified in this context. ${ }^{12}$

Straightforward asset purchase is not, of course, the only form of business acquisition. Especially when the target company's management opposes the sale of the firm, the acquiring company may seek to effect the acquisition by cash tender offer for the target's shares. Such an offer, again at a premium over the current share price, may be for all of the target's stock and is rarely for an amount less than that which would assure control to the acquiring company. Assuming the tender offer succeeds, there will always remain some untendered shares outstanding, whether through inertia or because the tender price is thought too low by a minority of the stockholders. Often in these circumstances the acquiring company will act promptly to eliminate the untendered shares by merging the target company with itself or with a wholly owned subsidiary created for that purpose. Since the acquiring company now controls the target, it can unilaterally set the terms of the merger and vote through its approval.

Quite obviously, however, the two steps in the acquisition-tender offer plus merger-are integrated and represent a "plan." The analogy to a unitary purchase of assets is close and compelling; the only major difference is the absence of initial approval of the takeover by the target company's board, a factor that may increase, rather than reduce, the total price paid by the acquirer. ${ }^{13}$ Although the tag-end merger appears to be an example of self-dealing by the majority stockholders, it is only superficially of that class. Realistically, the tender-plus-merger procedure is merely a way of bypassing the target company's proxy machinery, which is controlled by the incumbent board, and submitting the acquisition proposal to direct referendum of the stockholders. Those who accept the tender offer are properly to be regarded as aye-voters, those who do not, as nay- or non-voters. Tender by a majority is the equivalent of a conventional majority vote; the subsequent merger merely gives effect to the majority's decision to accept the terms of the acquisition. The requisite "vote" has already been

12. See Eisenberg, The Legal Roles of Shareholders and Management in Modern Corporate Decisionmaking, 57 CALIF. L. REv. 1, 72-74, 84-86 (1969). Eisenberg does not argue that appraisal should be eliminated. For an even more pessimistic view, which concludes that appraisal remedies are rarely of advantage to either shareholders or corporations, see Manning, The Shareholder's Appraisal Remedy: An Essay for Franh Coker, 72 YALE L.J. 223, 234-35, 238, 260-62 (1962).

13. See Troubh, Purchased Affection: a primer on cash tender offers, HaRv. Bus. Rev., July 1976, at 79,$80 ; c f$. note 18 infra (discussing circumstances in which tender offer may produce lower price than would result from good-faith bargaining). 
cast by the time the tender offer is completed, and the acquiring company is not really a voter in the original constituency at all.

In these circumstances, there really is no transaction between related parties and no self-dealing whatever. The acquiring company should be seen as an unrelated outsider throughout the takeover-from the time the tender offer is made to the time the merger is concluded. It has, or should be held to have, no fiduciary obligation as such, since as an outsider offering cash for the target's assets, it owes no duty to the stockholders of the sort that normally attaches to those who manage a firm or who own the controlling interest. It has no obligation to set a "fair" price for the target's property and should have no duty to disclose its management plans or to reveal any other values that it has discovered as an outsider. The heart of the takeover process is the exploitation of opportunities through the purchase of ownership and the substitution of new management. Seen as a takeover, the context is plainly not one in which fiduciary duty has any plausible or customary application. It is, literally, and despite the forced merger, an instance of arm's-length dealing.

The authors have suggested elsewhere that two-step takeovers, though not affected by fiduciary concepts, do require a modicum of regulation in view of the fact that public market transactions are involved and in view of the dangers of deception and "whipsaw."1t Thus we have proposed that tender offerors who contemplate a second-step merger be required to announce their intention at the time the tender offer is made. In addition, we think it appropriate that the price paid in the merger for the shares then outstanding be the same as the price offered on the initial tender. ${ }^{15}$ This "regulation" is designed both to apprise

14. Fair Shares at 330-40. "Whipsaw" refers to shareholders' rushing to accept the tender offer because they fear that, if the bid for control succeeds, they will be frozen out at a lower price. See id. at 337 .

15. To force the later merger at a price other than the tender price raises questions either of adequate disclosure in the tender solicitation or of fairness in the merger. For a discussion of the problems of allowing a lower merger price, see id. at 336-40; cf. Brudney, supra note 8 , at $1054-55$ (permissibility of two-step mergers should be tied to fair price rule). But cf. Borden, supra note 8 , at 1006-07 (arguing that in going-private mergers, merger price should be set just below tender price to prevent shareholders from holding back in tender offer in hopes of obtaining higher price). Judicial failure to consider this problem is reflected in Schulwolf v. Cerro Corp., 86 Misc. 2d 292, 380 N.Y.S.2d 957 (Sup. Ct. 1976). The judicial lapse in this matter may have resulted from the court's misplaced concentration on the question of "business purpose," which is quite irrelevant in a two-step merger.

As pointed out in Fair Shares at 335, 338, it may be difficult to determine whether a merger is in fact the second step in an acquisition, and some rule of thumb, perhaps one that raises a presumption of initial intent to merge if the merger in fact follows within a specified time, is needed, see id. at 340 n.87; cf. Green, supra note 8 , at 493 n.23 (proposing one-year rule). Even if the acquirer initially intends to obtain $100 \%$ of the 
stockholders that the initial tender offer, even if for less than one hundred percent, may eventuate in an acquisition of all of the target's shares, and to protect stockholders from being stampeded into accepting the tender price by the prospect of being forced to accept a lower price on merger if the tender succeeds. The aim here is to prevent the two-step nature of the acquisition from being concealed or improperly exploited; hence the rules are chiefly procedural and do not go to price or any other question of substantive fairness except in the respect that they require all stockholders to receive a pro rata share of the sale proceeds. ${ }^{16}$ Most particularly, no effort is made to raise the issue of "business purpose." Takeovers by outsiders must be assumed to have a commercial goal that suffices by itself to justify the transaction.

Somewhat ironically from our standpoint, Singer v. Magnavox Co. not only involved a two-step asset acquisition, but even appears to have met the procedural requirements stressed in the preceding paragraph. A less promising case for the assertion of the need for business purpose is therefore difficult to imagine. In August 1974, North American Phillips Corporation offered to acquire all the shares of Magnavox for cash at the rate of eight dollars per share. The tender offer advised that North American intended to acquire the entire equity interest in Magnavox and that it would, depending on the number of shares acquired, resort to "a merger, a sale or exchange of assets, liquidation or some other transaction" to carry out its aim. The directors of Magnavox voted to oppose the offer on the ground, among others, of inadequacy

target's stock, such intent is not enough to justify classifying a later merger as "two-step" if the acquirer delays while economic uncertainties affecting the acquired company are resolved. In such cases, fairness in the merger may require not only that the acquirer bear the risk of failure by paying the tender price, but also that it share the benefits of success by paying a higher price if the acquired company's value has increased. For a case that may fit this hypothetical, see Young v. Valhi, Inc., Civ. Nos. 5428, 5430 (Del. Ch. Feb. 22, 1978).

16. This conclusion is subject to qualification if the takeover is effected with the purchased cooperation or neutrality of the management of the target company. In that case, as when the management of an acquired company in an apparently arm's-length merger is bribed by the acquirer, the dealing is no longer accurately characterized as being at arm's length, and fiduciary constraints become relevant in appraising the propriety of the transaction. Though it is not easy to tell when the cooperation or neutrality of the target's management has been purchased rather than given on the merits, that probability becomes more than trivial when negotiations between the target's management and the bidder's management result in elimination of the former's publicly cxpressed opposition, notwithstanding that such change in position is accompanied by an increase in the tender price. Hence the judicial task in assessing challenges to two-step mergers is not confined to assessing the adequacy of the disclosure in the tender solicitation to induce the consent of the tendering stockholders. It may-at least if the tender is not "overhead," i.e., over the opposition of the target's management-include an inquiry into the circumstances surrounding the acquiescence of the target's management. See Fair Shares at $340-44$. 
of price, and expressed shock at an eight-dollar offer in the face of an eleven-dollar per share book value. In September the differences were compromised, with the Magnavox officers receiving new employment contracts and the offering price being raised to nine dollars per share. Roughly eighty-four percent of Magnavox shares were tendered. Some eight months later, North American absorbed the remaining sixteen percent by merging Magnavox with a wholly owned subsidiary. The price paid on the merger was the same as that offered in the tendernine dollars per share-and was also paid in cash.

Dissident stockholders challenged the merger on the grounds that it served no business purpose other than the elimination of the minority stockholders, that the cash price was inadequate, and that the merger violated the antifraud provisions of the state Securities Act. Reversing the court of chancery, which had held that appraisal was the sole remedy for dissenting stockholders, the supreme court ruled that cash-out mergers were an "abuse" under Delaware law unless the acquiring company could demonstrate a business purpose independent of the cash-out. It added, citing the well-known Sterling case, ${ }^{17}$ that even if such a business purpose were shown to exist, the merger would still be subject to attack on grounds of "fairness"-presumably a reference to the adequacy of the price paid to the minority. North American thus had to surmount the double barrier of business purpose and fair price before the merger would be approved.

As we have tried to suggest, however, the transaction in Singer does not appear to be of the kind to which the customary trappings of fiduciary duty should be attached. The merger of Magnavox into North American was, apparently, nothing more or less than the concluding step of a business purchase by an outsider. Since fiduciary limitations would have been irrelevant had such a purchase taken a unitary form, it seems undesirable to impose them on what is essentially only a variant procedure, one that is likely, if the tender is made over the opposition of management, to yield a higher price for the seller's shares than would the single-step alternative. ${ }^{18}$

17. Sterling v. Mayflower Hotel Corp., 33 Del. Ch. 293, 93 A.2d 107 (1952).

18. In some instances, however, a tender offer, even an overhead tender, may not produce a price for the target company's assets as high as that which would be produced if the target company's management were bargaining faithfully and singlemindedly to obtain the maximum price. The element of coercion in the tender, even the overhead tender, and in any event the absence of genuine bargaining by a knowledgeable representative, permits the bidder to set the price at an amount it deems just enough to attract the dispersed and uninformed stockholders of the target. The bidder has no obligation to inform them about the hidden assets of their company even if it knows of any. To be sure, the bidder's price cannot to too low if the management of the seller opposes the 
The court's error, in that view, is the consequence of a mistake in identification. Because minority stockholders were being paid off in cash, the court at once concluded that the transaction was a freezeout and therefore decided that the requirements of business purpose and fairness should apply. But the danger in a freezeout is that a majority stockholder who is in fact an insider will force the minority to accept an unfair price for their interests. North American was, of course, the majority stockholder in Magnavox at the time the merger took place, but it became so only by reason of the tender offer that immediately preceded the merger. The merger terms satisfied the requirement we would impose, namely, that the acquirer be bound by the tender price that the majority of the target's stockholders have accepted, and that it not be allowed to set new terms after becoming an insider. If the tender and the merger are viewed as integrated steps, then the Magnavox stockholders were no more frozen out by North American than are nay- or non-voting stockholders in a one-step purchase of assets. Rather, those Magnavox shareholders who tendered their stock to North American compelled the nontendering minority to accept the same cash payment for their shares in the subsequent merger. Since all stockholders of the selling company received the same price per share, appraisal should indeed have been the only remedy available to dissenters who thought the price accepted by the majority was too low. Once the tender-plus-merger procedure is equated with the unitary sale of assets, the same legal status should result.

From another standpoint, it is possible that the Delaware court was concerned about the compromise between the managements of North American and Magnavox, which included new employment contracts for the latter. Indeed, this may have been a crucial factor, for it raises the question whether the transaction was truly arm's length, or whether the Magnavox management had in fact received a personal consideration for its change of position. This may partly explain why

tender and is able to reveal reasons for the target's stock being worth more, or indecd seeks to find another purchaser at a higher price. But there is reason to belicve that a tender offer is likely to be made at a price lower than would result from a bargain bctween two maximizers. This fact, if it be one, does not implicate the fiduciary obligations attending absorption of a long-held subsidiary by a parent. The buyer, by definition, is a stranger and therefore does not have a parent's fiduciary obligations of disclosure or of fair dealing. If the seller's management has failed to disclose hidden assets but has not been bought out by the buyer, then its failure is, at most, a failure of care, a matter of business judgment on which the law is notoriously elastic. In short, the question whether dispersed public stockholders are properly exposed to the risk that an overhead tender will give them less than would an organized bargain on their behalf poses interesting issues in corporate law, but it does not implicate the fiduciary duties or the question of "fairness" involved in the merger of a long-held subsidiary into its parent. 
the supreme court directed the court of chancery to reexamine the "entire fairness" of the transaction on remand. Just how such a reexamination is to be carried out remains something of a mystery. But to the extent that the assignment of that task reflects an alert interest in the bona fides of the target's management in the takeover, the new, or renewed, enforcement of fiduciary obligation in Singer is a welcome development in the jurisprudence of this vital jurisdiction. It does not detract from that conclusion to insist that, in the absence of reason to question the bona fides of the target's management, the pattern of overhead tender plus merger at the tender price is one in which issues both of "purpose" and of "fairness" are beside the point.

\section{B. Going Private}

Going-private transactions of the sort that have made financial headlines in recent years exhibit a factual pattern quite distinct from that of the two-step merger. ${ }^{10}$ Here, controlling stockholders who are responsible for the company's management, having determined that its shares are undervalued by the market relative to its prospects and expectations, seek to terminate the public stockownership and return the firm to the status of a closely held entity. Typically, the insiders create a holding company, to which they transfer their controlling shares, and then propose a merger of the operating company into the holding company. ${ }^{20}$ The plan is that public stockholders of the operating company receive cash (borrowed by the operating company or drawn from its working capital) equal to the current market value of their shares plus a premium, while the insiders emerge as sole owners of the equity. Quite obviously, the insiders are not engaged in a takeover as North American was in Singer, because by definition they controlled the firm to start with. They aim simply to increase their investment interest from a controlling fraction of the company's stock to one hundred percent.

The "fiduciary" status of the controlling stockholders in these circumstances is presumably beyond question, and it is here, no doubt, that Singer's close scrutiny of the insiders' motives is best applied. Indeed, it has been argued that the impact of "fiduciary duty" should be

19. See, e.g., Jutkowitz v. Bourns, No. C.A. 000268 (Cal. Super. Ct. Nov. 19, 1975); Berkowitz v. Power/Mate Corp., 135 N.J. Super. 35, 342 A.2d 566 (1975).

20. Often the merger is preceded by a tender offer by the company for its own shares. As suggested at p. 1370 infra, the tender and the merger are plainly integrated steps and, hence, should be dealt with as a unit. See Note, Going Private, 84 Yale L.J. 903, 909-11 (1975). 
even stricter than Singer suggests, ${ }^{21}$ and that insiders simply ought not to be permitted to use corporate processes to eliminate the public interest in the firm. Although insiders may of course purchase shares in their individual capacities by bidding for them in the market, the exploitation of the corporate proxy machinery, to which they alone have access, for the purpose of forcing public stockholders to give up their shares is regarded as a significant "abuse" in all but "exceptional" situations. In this view, the element of sheer coercion is fatally objectionable. Others find unfairness in the circumstance that the firm, having gone public when the market was buoyant and high, now elects to go private when the same market is depressed, and will presumably go public again when market averages recover. Taking advantage of market swings-first sucking in the public's money, and then squeezing out the public's participation-is deemed a misappropriation of a corporate asset. ${ }^{22}$ Still other critics have urged that existing standards on disclosure of inside information, though adequate to regulate individual market purchases, simply never can be stringent enough to prevent abuse when the entire minority interest is forced out through a merger. ${ }^{23}$ Timing, as well as price, is within the discretion of the majority, and even if all relevant financial information has been disclosed, it is argued, insiders ought not to be allowed to act on their own interpretation of the data by compelling other stockholders to accept a more pessimistic view of the company's outlook than the one they hold themselves.

From the standpoint of the corporation, the justification commonly offered for going private is that the elimination of public investors will enable the company to save the legal and accounting costs of complying with SEC and stock-exchange disclosure requirements as well as the expense of carrying on stockholder relations in one form or another. This, however, is an inadequate justification, and in many instances we would doubt its sincerity. The costs of monitoring management's conduct are incurred for the benefit of the public stockholders, and it hardly rests with the fiduciary to cite the saving of those costs as a reason for terminating the beneficiaries' interest without their consent.

21. Brudney, supra note 8 , at $1029-30,1030 \mathrm{n} .42$ (if neither appraisal rights nor fairness test protects public stockholders in going-private context, courts can exercise traditional equity powers to prohibit going-private transactions when there is no unanimous stockholder consent).

22. Note, supra note 20 , at 931 .

23. This appears to be the conclusion of the Securities and Exchange Commission (SEC) in proposed rules 13e-3 and 13e-4. See S.E.C. Release No. 33-5884 (Nov. 23, 1977), reprinted in [1977-78 Transfer Binder] FED. SEc. L. REP. (CCH) 81,366 [hereinafter cited as SEC Release]. 
Moreover, the amount of that saving, measured per share of stock outstanding, is too small in most cases to explain the company's actionitself costly-in retiring a major fraction of its stock. The Singer decision strongly implies that a corporate purpose is necessary to sustain the legal validity of going private. To meet that condition, the proponents should be required to show that public stockownership is actually inconsistent with the company's continued viability, not merely that public ownership entails a cost that can be avoided by eliminating the public's interest. But we are not aware that such a showing has ever been made in a going-private case, and we doubt it ever could be. As suggested above, takeovers by outsiders, which may include merger as a second step, must be assumed to involve at least the possibility of an improvement in the target company's management. And as suggested below, mergers between affiliated corporations may entail economic and related benefits in the form of "synergy" or the like. By contrast, going private simply shifts publicly owned stock into the hands of the insiders and promises no economic gains to the enterprise that can be regarded as significant.."

With so little to justify dilution of its strictest mandate, the fiduciary principle suggests that going private transactions should in all cases be prohibited. This approach would interpret corporate statutes-as we believe they were intended to be interpreted-as not permitting insiders unilaterally to condemn the stock of public investors when the effect is to leave the public with no chance to return to the enterprise. Merger legislation that authorizes exclusion of public stockholders serves its purpose if read as permitting pay-outs in cash or senior securities only in two contexts: in take-overs or sell-outs at arm's length and in those self-dealing mergers that permit the displaced public investor to reenter by using the condemnation price to purchase new participations in the continuing merged enterprise. Where no such reentry is possible, ${ }^{2 \bar{s}}$ the statutes need not be read to permit the freezeout, no matter how high the condemnation price, unless specific

24. See Brudney, supra note 8 , at 1028-29. It has been argued that policy considerations favor going private, because it decreases costs associated with public ownership, protects against takeovers, and assures that control will remain in the hands of the insiders, who have the largest stake in the enterprise. Borden, supra note 8, at 1013-14. These arguments beg the question whether the benefits of going private belong solely to insiders or must be shared with all stockholders. Indeed, Borden himself concludes that a price set by insiders "should be presumed to be ... unfair," id. at 1018, and formulates a rule for allowing reentry into the enterprise if it again goes public, $i d$. at 1039-40; see note 28 infra.

25. Rules requiring reentry have indeed been proposed, but they would operate only if the company again went public and in any event do not seem feasible. See note 28 infra. 
language expressly authorizes "going private."

Even were there no such "constitutional" objection, the merger statutes should properly be construed to permit the displacement of public investors only if the displaced stockholders receive fair treatment. But going private, by its very nature, offers no feasible means of determining whether public stockholders have in fact been fairly compensated for their interests. If taking the firm private increases its value by reducing accounting and legal fees and the cost of relating to public stockholders, determining the displaced stockholders' fair share of the increment thus expected to result from their displacement presents intractable problems. To quantify the benefits embodied in the explicit justifications offered for going private would be difficult enough. But if account must also be taken of the unspoken benefits, such as tax advantages and other perquisites, ${ }^{26}$ that would accrue to the controlling stockholders as a result of being freed of public accountability, the problem of implementing a fairness standard comes close to being insurmountable.

Moreover, the unavoidable suspicion is that the insiders will elect to go private at a moment in time that they perceive as a turning point in the company's affairs-but before that perception has become general. In these circumstances, the danger that the public stockholders will be undercompensated is too great to tolerate. To be remitted at such a time to statutory appraisal rights or to a costly if not impossible fairness proceeding by their own management is not only a serious disservice to the public stockholders, but also (in Singer's words) "an abuse of the corporate process." The problem is compounded by the fact that, once a public market for the company's securities has been eliminated, no reliable basis remains for judging whether the ousted stockholders were fairly compensated for their interest. The impact of subsequent events on the value of the company's shares obviously cannot be determined, for even hindsight is blinded when the company is closely held.

In this setting neither "business purpose" nor "fairness" provides a test or a justification for separating permissible from impermissible cases of going private. The economic value of eliminating SEC monitoring expenses and similar costs is simply not sufficient to overcome the likelihood that public stockholders will be cheated or to justify the cost of prevention. Given the absence of social benefit, the strength of fiduciary obligation, and the danger of unpoliceable abuse, the

26. See, e.g., SEC v. Parklane Hosiery, Inc., 558 F.2d 1083 (2d Cir. 1977) (availability of company funds to discharge personal debts). 
simplest and the best response the corporate law can make to goingprivate transactions is a flat prohibition.

It has been argued, however, that, apart from the concerns just expressed, there are a significant number of publicly held corporations whose stock is not sufficiently widely distributed to be traded, so that public stockholders have a thin market, if any, and therefore are locked into the company. Permission to unlock their positions by buying them out for cash is said to be manna to them. ${ }^{27}$ We do not know how many such companies-which are "public" but lack an active market for their shares-exist. But however numerous they may be, the notion that because the market for its stock is "thin," the corporation should be able to force its stockholders out, with no feasible test of fairness, simply asserts that stockholders have no entitlement to their stock so long as insiders deprive them of it at any price above the market price. That surely is not a tolerable norm under the received learning or under any other values that underlie the corporate system. Nor is it self-evident that, if the insiders are forbidden from using corporate cash to displace the outsiders, the latter will be intolerably locked in, or indeed will be worse off than under a rule permitting them to be frozen out at or above market price. If the enterprise is failing or headed for worse times, insiders will not seek to buy out outsiders. If it is headed for better times, strangers may well be willing to pay an arm's-length price, and to pay it to all the stockholders, not just to the insiders. And it is at least arguable that if no strangers appear, the increased prosperity of the enterprise will be shared more readily with outsiders if they remain locked in than if they can be forced out. Certainly, before rejecting the command of the fiduciary principle categorically to prohibit going private, empirical evidence of the need for a more selective rule is required. All the suggested forms of a more selective rule imply a restraint on insiders equivalent to a requirement of some sort of fair treatment, but none offers a feasible test of fairness. ${ }^{28}$

27. Borden, supra note 8 , at 1003 .

28. To condition "going-private" transactions on a second look at the enterprise after a year or two to determine whether the public received an adequate price in the freezeout, as suggested in, e.g., Borden, supra note 8 , at $1039-40$, or to give the minority rights to rescind their forced sales or warrants for repurchase in case the company goes public again, see id.; Note, supra note 8, at 929-30, leaves the problems of defining adequacy, i.e., fairness, and of reexamining or reconstructing corporate behavior during that interim. Although enforcement by examination of corporate performance during the years after the transaction to ascertain how its value assumptions have been borne out offers more protection to public investors than does enforcement as of the date of merger, the delay does not aid in defining the substantive standard of fairness or remove enough of the difficulties of enforcement to ensure substantial compliance.

In SEC Release, supra note 23, the SEC has proposed, as restraints on going private, requirements of disclosure and, in some cases, of fairness. The nature and import of the 
Finally, we would extend the prohibition against going private to two-step arrangements in which the merger is preceded by a tender offer from the company itself. As in the case of a tender offer by an outsider followed by merger, two-step and one-step arrangements should be assimilated and treated alike. Here, however, the factor of like treatment points to the opposite conclusion: an absolute prohibition against going-private transactions, whether consummated in one step or in two.

\section{G. Mergers of Affiliates}

Yet a third, and a different, regulatory problem is presented by a proposed merger between a parent company and a subsidiary corporation that the parent has controlled for a more or less extended period of time. Here, as in the going-private context, the aspect of fiduciary duty is clear. The parent's status as majority or controlling stockholder is one that has long been held to carry with it a special obligation to the minority stockholders of the subsidiary. In addition, it is necessarily the case that both companies are managed, ultimately, by a single board of directors, whose obligations of loyalty and care run equally and concurrently to both sets of public stockholders-those of the subsidiary as well as those of the parent. We suggest below that it may conceivably make a difference whether fiduciary duty is rested on majority stockownership or on the factor of joint management respon-

transaction are apt to be illuminated adequately in advance by the proposed requirements for disclosure of the insiders' purposes and their plans or proposals for the corporation, see id., Schedule 13E-3, Items 5-6, and of the bases for determining the amount and kind of consideration offered and the fairness of the transaction, see id. Schedule 12E-3, Items 9-10. Those disclosures will undoubtedly help stockholders to respond knowledgeably to a tender offer by the issuer. But although they may dilute, they will not eliminate the elements of coercion in the transaction. Nor will disclosure induce enough negative votes to abort the merger if the insiders control enough stock or even just the proxy apparatus. In apparent recognition of the limited effectiveness of disclosure, the Commission's proposal also seeks to assure fairness, at least in going-private transactions by companies with stock registered under $\$ 12$ of the Securities Exchange Act of 1934, 15 U.S.C. $\$ 781$ (1970 \& Supp. V 1975). See Proposed Rule 13e-3(b), in SEC Release, supra note 23. Although the proposal lists several relevant considerations that in some indeterminate mix can produce a conclusion of fairness in any particular case, it offers no standard of fair treatment. To combine the SEC's proposal (assuming it is authorized by the present statute) with the suggestions for a "second look" would preserve the sell-out opportunity for public investors in "worthy" cases (i.e., where there is a thin and depressed market) and at the same time would impose constraints on the going-private process that would produce significant benefits for public investors, possibly even "fair" treatment, if some of the considerations listed by the Commission dominate the decision on fairness. However, to the extent that it has significant "bite," any such combination of remedies is not likely to differ in consequence from our proposal, because of the probability that it will discourage insiders entirely from going private. Their decisions would be affected by fear of being held liable for nonculpable false statements if subsequent improvements in the condition of the enterprise were not anticipated in the information disclosed. 
sibility. For the moment, however, it suffices merely to confirm what is everywhere conceded, namely, that the parent must deal "fairly" with subsidiary's stockholders, and that affiliation implies a special obligation of some sort.

Mergers between affiliates are thus distinguishable from two-step takeovers, which are essentially arm's-length deals between unrelated parties. But though obviously not at arm's length, affiliated mergers offer private and social benefits of sufficient importance to distinguish them from pure going-private transactions as well. Moreover, they can feasibly be tested for "fairness."

In many instances, the merger of a partly held subsidiary into its parent is designed to achieve operating economies or other economic gains that are unavailable, or less readily available, when the two firms are maintained as separate entities. Elimination of duplicated functions, tax savings, and financial and stock market gains are among the benefits commonly cited as potentially realizable through unification of parent and subsidiary. These may or may not be substantial factors in a particular case, but the possibility that joint ownership can result in a larger overall value for the two firms than the sum of their values as separate companies makes it impossible to deny that a business purpose may exist, and exceedingly difficult, in any given case, to prove that a commercial goal for the merger is wholly lacking. If the elimination of the separate subsidiary does or even can produce a larger aggregate, then presumably that step should not be discouraged and must not be prohibited.

Even if "synergistic" gains of the sort just described were minimal in a particular instance, there is a sound and creditable reason for management to want to reduce to one the number of stockholder constituencies to which it is legally responsible. The difficulty of placing intercompany dealings on a fair basis, of allocating overhead costs and (where relevant) tax benefits between the companies, and in particular the nearly impossible task of attributing opportunities for growth and diversification to the "appropriate" unit ${ }^{29}$-these and related fiduciary problems present issues of practical day-to-day administration that are notoriously hard to solve. Corporate law spends much of its time policing fiduciary conflicts, and all the sanctified literature in the field is directed against the danger of serving two masters. It is not easy, therefore, to take the position that a legal mechanism, even such a mechanism as contrived merger, that aims to dissolve an existing conflict by bringing one such relationship to an end should be unavail-

29. See David J. Greene \& Co. v. Dunhill Int'l, Inc., 249 A.2d 427 (Del. Ch. 1968); Fair Shares at 308. 
able. ${ }^{30}$ We would urge that, from the standpoint both of internal management and of sound administration of the company laws, the simplification of parent-controlled subsidiary structures through merger should be viewed as inherently "purposive." Congress itself gave recognition to this idea in a related area when it mandated the simplification of complex public utility holding company systems. Probably, self-help simplification of the sort considered here deserves the same support-as indeed seems to have been the conclusion of those legislatures that first enacted short-form merger statutes.

To conclude that mergers between publicly held parents and subsidiaries serve ends sufficiently desirable to preclude categorical prohibition of such transactions does not end the inquiry. As the authors have suggested elsewhere, ${ }^{31}$ that conclusion underscores the need for a rigorous "fairness" test. Such a test should assure that the subsidiary's stockholders are enabled to maintain their participation in the combined enterprise if they so desire. Although ideally this goal should be carried out by requiring that the subsidiary's stockholders be offered common stock in the parent, ${ }^{32}$ state laws frequently depart from this

30. In this context the enforcement of fiduciary norms is a serious problem even when management behaves in a perfectly neutral fashion and makes every effort to treat the stockholders of both companies evenhandedly. Here, however, the problem is largely "administrative," viz., to make sure that intercompany dealings are fairly structured as between the two entities. It is not (or not solely) a question of restraining managers from pursuing their own self-interest at the stockholders' expense.

In the going-private context, by contrast, there is only one legally recognizable claim to management's best efforts-that of the company's stockholders, inside and outside alike. The goal of evenhanded treatment presents no administrative difficulties as such, because the corporate law recognizes no more than a single constituency. Allocation and fair division problems should not arise unless management improperly creates two constituencies by attempting to treat insiders and outsiders differently. Compliance with fiduciary norms is not a matter of sorting out legitimate but conflicting claims, but of living up to a standard of loyalty and care that is generally well understood.

Concededly, there are costs associated with fiduciary compliance in both of the above contexts. The parent-subsidiary context, however, presents more reasons to fear overreaching by the parent and therefore, as the English law suggests, more reasons to encourage elimination of the subsidiary's minority. See R. Moon, Business MERgers AND TAKE-OVER BIDS 140-41 (4th ed. 1971). The cost of compliance relating to parent-subsidiary dealings can be eliminated by uniting the two groups of public stockholders, but those relating to management self-interest can be eliminated only by terminating public stock ownership entirely. In the parent-subsidiary context, the "fairness" test provides a safeguard. In the going-private context, there is simply no reliable protection against the danger of undercompensation of the public stockholders.

31. Fair Shares at $307-09$.

32. See Brudney, supra note 8 , at $1023,1027,1038$ n.69 (noting problems of disparate forms of payout, including those of finding acceptable new investment, of determining equivalent values, and of reacquiring stock in parent, and concluding that offering stock: in parent is best solution); Green, supra note 8 , at $508 \mathrm{n} .68,512$ (proposing that mergers between companies affiliated for five years or more be allowed only if stockholders of merged entity retain equity interest in merged enterprise; for mergers of companies affiliated for one to five years, administrative body should determine fair price). 
ideal by permitting debt or cash as well as stock to be paid out in a merger. ${ }^{33}$ Even so, the standard of fairness should dictate that the recipients receive enough in value to enable them to reacquire the same proportionate interest in the parent that they would have possessed had the consideration received been common stock alone. Under this standard, the use of cash in an affiliated merger is to be seen as involving an exchange of the parent's common shares for those of the subsidiary, followed by the parent's repurchase of a portion of its "outstanding" stock. The direct use of cash in the merger collapses these two steps into one, but the use of a shortcut (if permitted) should not be allowed to disadvantage the minority stockholders.

This approach, we think, implies a "proportionate sharing" rule of the kind applied by the Seventh Circuit in Mills v. Electric Auto-Lite $C o .^{34}$ In Auto-Lite the court found that the premerger value of the subsidiary's publicly owned shares was about $\$ 28$ million, that of the parent $\$ 67$ million-a total of $\$ 95$ million. The postmerger value of the securities of the combined enterprise was $\$ 99$ million. Hence the increment in value resulting from the merger was roughly $\$ 4$ million. Since the minority shares of the subsidiary constituted twenty-nine percent (28/95ths) of the total premerger value of the stock of both companies, the court held that the transaction would be treated as "fair" if-and, indeed, found it to be "fair" because-the minority stockholders received consideration worth not less than the premerger value of their shares plus twenty-nine percent of the "merger increment." 35

33. See note 11 supra; Brudney, supra note 8 , at 1029 \& $n .39$. Both the historical and functional demands of the short-form merger statutes can be fully met by confining their application to mergers between publicly held parents and subsidiaries, subject only to a test of fairness. See Kemp v. Angel, 381 A.2d 241, 245 (Del. Ch. 1977).

34. 552 F.2d 1239 (7th Cir.), cert. denied, 46 U.S.L.W. 3293 (U.S. Nov. 1, 1977).

35. Id. at 1248-49. The court's exclusive reliance on the market prices of the parent's and subsidiary's stocks in applying the formula may well have been misplaced. Notwithstanding the court's rejection of the specific distortions claimed for the market prices of the stocks involved, other considerations suggest a more or less systematic distortion of the prices of the stocks of subsidiaries, if only because of the overhang of a control block. Moreover, the price of the subsidiary's stock is also affected by the market's perception of the likelihood of improper diversion of the subsidiary's assets by the parent, see, e.g., David J. Greene \& Co. v. Schenley Indus., Inc., 281 A.2d 30, 35 (Del. Ch. 1971); In re Talley Indus., Inc., 44 S.E.C. 165, 180 (1970); $c f$. Tanzer v. Haynic, 405 F. Supp. 650, 654 (S.D.N.Y. 1976) (fair price for minority stockholders includes consideration of earnings and prospects); and by concealment of information or impediments to the flow of information about future derelopments known to the parent.

Evidence from other contexts supports the proposition that market price is often a poor indicator of valuc. It has becn observed that there is a systematic disparity between market prices and portfolio values of the stocks of closed-end investment funds, Malkiel, The V'alualion of Closed-End Investment Company Shares, $32 \mathrm{~J}$. Finance 847 (1977), and a systematic inadequacy of market price to measure value in insolvency reorganizations, 
Under Auto-Lite, therefore, if the value of a merged entity exceeds the summed values of the parent and subsidiary taken separately, the increment must be divided between both sets of stockholders in proportion to the premerger values of their respective shares. Once again, the simplest and least costly method for assuring "fairness" under this formula is for the parent to issue its own common shares to the subsidiary's stockholders in a ratio reflecting the values of each set of shares just prior to the announcement date. ${ }^{36}$ But the benchmark is the same for payments in cash or debt: after the merger the former stockholders of the subsidiary must be in a position to participate in the combined enterprise as fully as if payment had been in stock. By requiring that any merger increment be shared proportionately, Auto-Lite helps to assure that this objective will be met. Its virtue is that it prevents freezeout by putting minority stockholders in a position to reacquire their investment in the enterprise without dilution.

To be sure, this approach distinguishes between cases where the parent is closely held as a result of a merger and cases where the parent remains a public company, but the distinction is both proper and inherent. If the acquiring parent is "private," the use of cash or debt may be unfair per se, because there is then no means for minority stockholders to reacquire an equity interest-they are truly frozen out. And, of course, there is no feasible way to determine whether the freezeout price was fair. But when the parent is a public company, the individual cash or debt recipients are free, if they wish, to restore their participation by purchasing its shares in the market. That a "transaction" is required is simply a cost (possibly one that ought to be reimbursed) of using cash or debt instead of stock, but the exchange is nevertheless "fair" if the amount received is sufficient to enable a recipient to obtain the same stock interest that he would have had if

see Altman, Bankrupt Firms' Equity Securities As an Investment Alternative, IiN. Axulsis J., July-Aug. 1969, at 129; W. Blum, The Law and Language of Corporate Reorganization, 17 U. CHr. L. Rev. 565 (1950); W. Blum, Full Priority and Full Compensation in Corporale Reorganizations: A Reappraisal, 25 U. CHI. L. REv. 417 (1958); M. Blum, Failing Company Discriminant Analysis, $12 \mathrm{~J}$. Accounting Research 1, 11-12 (1971). Considerations comparable to those that distort market prices in cases of closed-end funds and insolvency reorganizations affect the market prices of parent's and subsidiary's stocks. In such cases, therefore, it is necessary to determine the values to be compared by reference to "intrinsic value" rather than simply to rely on market price. Cf. Fair Shares at 323-25 \& n.56 (difficulties of determining "value" exist but should not be much greater than at present and should not be reason for rejecting most appropriate solution to fairness problem in parent-subsidiary mergers-payment of fully adequate values). It is, of course, possible that in Auto-Lite the same result would have been obtained by focusing on intrinsic value.

36. These "values" are not likely to be determined by market prices, whether current or averaged over any prior period. See note 35 supra. 
the parent had issued its shares in a ratio reflecting the premerger values of the companies. The effect then is to allow management to unite its stockholder groups without preferring one group to the other. Minority stockholders are compelled to accept homogenization on the ground that private and social values justify that much compulsion, but the Auto-Lite formula assures that it is only forced homogenization, and not exclusion or dilution, that will result.

Tanzer v. International General Industries, Inc.37 apparently fits this factual pattern. The parent corporation merged with its eightyone-percent-owned subsidiary, paying off the minority stockholders in cash. The parent-subsidiary relationship was evidently longstanding. Reacting to Singer, the parent asserted without contradiction that the "business purpose" for the merger was to facilitate the parent's own long-term debt financing, presumably by enabling it to use the subsidiary's tangible assets directly, as loan security. The Delaware court found this to be a legally adequate "purpose" but then remanded the case for a further finding on whether the consideration paid to the minority was "fair."

If the fairness standard is correctly applied on remand in conformance with the Auto-Lite formula, the outcome in Tanzer is one that deserves approval. As indicated, however, the business-purpose recital seems altogether unnecessary in this context and even potentially distorting. If, as the court said, a majority stockholder can act in its own interest and without concern for the economic interest of the minority, then it might seem to follow that the majority owes no more to the minority than would an outsider seeking to take the subsidiary over. But this latter conclusion suggests that the parent can reserve to itself the economic value of the merger, which is contrary to the position taken in Auto-Lite. Thus Auto-Lite implies that management should be seen to have the same fiduciary obligation to the stockholders of both concerns and, accordingly, that any benefit resulting from the merger must be shared proportionately.

Our own view is that no allegation of business purpose, whether parent's or subsidiary's, need be made in cases of this sort. Indeed, an excessive concern with business purpose may actually divert the courts from focusing attention on fairness and other relevant considerations. ${ }^{38}$

37. 379 A.2d 1121 (Del. 197i).

38. For illustrations of judicial focus on "business purpose" at the expense of adequate attention to the problem of fairness in the merger, see Young v. Valhi, Inc., Civ. Nos. 5428, 5430 (Del. Ch. Feb. 22, 1978); Schulwolf v. Cerro Corp., 86 Misc. 2d 292, 380 X.Y.S.21 957 (Sup. Ct. 1976); Tanzer Economic Assocs., Inc. Profit Sharing Plan v. Universal Food Serrs., Inc., 87 Misc. 2d 167, 383 N.Y.S.2d 472 (Sup. Ct. 1976). 
The goal of homogenizing the two stockholder constituencies carries its own complete justification. What is needed, however, is a fairness rule that assures that any monetary benefits will be properly shared between the two constituencies, so that the only consequence of the merger is the simplification or improvement of the corporate structure.

\section{Conclusion}

Our aim in this article has been to stress the need for a plausible classification of freezeouts and to offer a coherent rationale for requiring different protective rules for public stockholders in each class. One way to summarize our approach is to say that it never permits a "true" freezeout. Two-step takeovers, being acquisitions by outsiders, are not properly to be viewed as freezeouts in the first place, any more than is a unitary asset acquisition approved by a majority of the seller's stockholders. Pure going-private transactions are indeed true freezeouts, and since their only serious aim is to enrich the insiders, they would be flatly prohibited in all cases. No fairness test can save them. By contrast, mergers between parents and partly held subsidiaries fall short of being true freezeouts because they do not irretrievably exclude public stockholders from the enterprise. Moreover, though obviously selfdealing, such mergers may be presumed to entail economic and related benefits for the enterprise itself, so that prohibition is undesirable. The appropriate solution is fairness, which can be attained either by restricting the permissible consideration to a proper proportion of the parent's common stock, or by assuring that the subsidiary's stockholders are placed in a position, through the receipt of cash or debt, to reacquire an equivalent proportionate stock interest in the surviving entity.

Under these rules the factor of "business purpose" is irrelevant. None need be shown in the two-step or in the parent-subsidiary context. In all likelihood, none exists in going-private transactions. The main effort, whether statutory or judicial, should be to identify the relevant context correctly and then to execute the appropriate scheme of safeguards. We do not pretend that this will always be a simple matter. If the proposed analysis is observed consistently, however, we would expect a material improvement both in the outcomes of litigated cases and in the capacity of company managers and their advisers to forestall litigation through planned compliance or forbearance. 


\section{The Yale Law Journal}

Volume 87, Number 7, June 1978

\section{Peter J. Kalis \\ Editor-in-Ghief}

William N. Eskridge

Note \&े Topics Editor

Matthew T. Heartney

Edward P. Krugman

Mark C. Rahdert

Note Editors
Richard H. Klapper

Managing Editor

David J. Grais

Charlotte G. Meriwether

David O. Stewart

Article of Book Review

Editors
Sheldon S. Adler

Michael J. Album

Scott D. Baskin

Wendell R. Bird

David M. Brewer

Donald F. Brosnan

Peter C. Canfield

Stephen L. Carter

Donald K. Cawley

William W. Chip

Gandolfo V. DiBlasi

James C. Francis IV

Eric M. Freedman
Susan L. Hoffman Edward E. Honnold

Gary S. Katzmann

Charles King III

Daniel L. Koffsky

Bruce R. Kraus

John J. Kulewicz

Kim J. Landsman

Lee J. Levine

Michael D. Lowe

William L. Lynch

Margaret P.P. Mason
Martha L. Minow

Mark L. Pelesh

Bradley S. Phillips

Carl L. Reisner

Edward L. Rubin

Joseph J. Sheehan

David M. Skover

Paul M. Smith

James F. Strnad II

Emily G.H. Sullivan

Bruce C. Swartz

Ellen E. Wright

Gerson A. Zweifach

Secretaries to the Editors M. Olive Butterfield, Pamela Willmott

\section{Student Contributors to This Issue}

Stephen L. Carter, Implied Rights of Action to Enforce Civil Rights: The Case for a Sympathefic View

Susan L. Hoffman, On Prisoners and Parenting: Preserving the Tie That Binds

Charles King III, Exceptions to Liability under Section 16(b): A Systematic Approach

Bruce R. Kraus, Preferential Transfers and the Value of the Insolvent Firm

Paul M. Smith, Medical Care, Freedom of Religion, and Mitigation of Damages

Ellen E. Wright, Father and Mother Know Best: Defining the Liability of Physicians for Inadequate Genetic Counseling 